\title{
KESENIAN SINTREN SEBAGAI KEARIFAN LOKAL DITINJAU DARI METAFISIKA ANTON BAKKER
}

\author{
Luthfi Deska Aditama \\ Fakultas Filsafat Universitas Gadjah Mada \\ email: deskamadridista@gmail.com
}

\begin{abstract}
Abstrak: Kesenian Sintren sebagai Kearifan Lokal Ditinjau dari Metafisika Anton Bakker. Kata "sintren" secara etimologis berasal dari dua suku kata, yang "si" dan "tren". Si memiliki arti "dia" dan tren itu sendiri adalah panggilan untuk sang putri. Seni ini adalah seni yang berasal dari pantai utara Jawa, khususnya Jawa Tengah, dan Jawa Barat. Selain itu, Sintren banyak dipamerkan di pameran besar kesenian yang bercerita tentang seorang anak perempuan yang bertindak sebagai penari utama. Sintren sebagai bentuk seni pertunjukan rakyat di Utara pesisir Jawa Tengah dan Jawa Barat pernah menjadi seni hiburan yang sangat digemari oleh masyarakat antara tahun 1950 hingga 1963. Metafisika adalah disiplin filsafat yang erfokus pada sautu objek - materi yang ada, atau dalam bahasa sederhana adalah sifat realitas. Sifat realitas tidak dapat dipisahkan dari alam, Sang Maha Benar (Allah) serta hamba-Nya (ciptaan-Nya). Pandangan manusia sebagai khalifah juga akan menentukan keberadaan makhluk lain, sampai akhirnya berkaitan dengan Yang Maha Kuasa, yaitu Allah.
\end{abstract}

Kata kunci: sintren, metafisika

Abstract: Sintren, Indigenous Art, in the term of Anton Bakker Metaphysics. The word "sintren" is etymologically derived from two words, the "si" and "tren". Si has the meaning of "she" and the 'tren' itself means "the princess". This art is the art that comes from the north coast of Java (Central Java and West Java). In addition, many Sintren exhibited in major art exhibition that tells the story of a girl who acts as a principal dancer. Sintren as a form of folk performing arts in the North coast of Central Java and West Java was once the entertainment art highly favored by the people between 1950 to 1963. Metaphysics is philosophical discipline that focuses on sautu object- existing material, or realistic material. The nature of realistic can not be separated from nature, the Almighty God and His creation. The view of man as caliph also will determine the existence of others, until finally deals with the Almighty God.

Keywords: art sintren, metaphysics

\section{PENDAHULUAN}

Indonesia adalah negeri yang kaya akan kebudayaan. Kebudayaan sendiri adalah keseluruhan sistem gagasan, tindakan dan hasil karya manusia dalam rangka kehidupan masyarakat yang dijadikan milik dari manusia dengan belajar (Koentjaraningrat, 1985: 180).

Setiap daerah di Indonesia memiliki kebudayaan masing-masing. Tari Sintren adalah kesenian yang ada pada pantura (pantai utara) Jawa, terutama daerah 
Jawa Tengah dan Jawa Barat. Sintren merupakan wujud kebudayaan berupa kesenian tari. Wujud kebudayaan ini ialah wujud kebudayaan yang paling konkret sebab dapat dilihat, ditampilkan dan didokumentasikan.

Sintren sendiri adalah kesenian tradisional masyarakat Jawa Tengah khususnya Pekalongan, Kendal dan sekitarnya, merupakan sebuah tarian yang berbau mistis/magis yang bersumber dari cerita cinta kasih Sulasih dan Raden Sulandono. Dalam kisah tersebut bahwa Raden Sulandono adalah putra dari Ki Bahurekso hasil perkawinannya dengan Dewi Rantamsari.

Setiap diadakan pertunjukkan sintren sang penerari dimasuki roh bidadari oleh pawangnya. Sintren diperankan seorang gadis yang masih suci (perawan), dibantu oleh pawangnya dan diiringi gending 6 orang. Pengembangan tari sintren sebagai hiburan rakyat, kemudian dilengkapi dengan penari pedamping dan pelawak.

Sintren memiliki banyak arti serta filosofi Anton Baker merumuskan problemproblem yang dapat menjadi bahan garapan metafisika. Sintren terutama yang berkaitan dengan metafisika dikaji dengan kacamata Anton Baker.

Pemikiran metafisika umum Anton Bakker menggali persoalan metafisika secara sistematis dan komprehensif. Penelitian menggunakan perspektif persoalan metafisika Bakker. Bakker tidak hanya membahas aspek metafisika yangada sebagaimana pemikir metafisika yang lain. Persoalan metafisika Bakker dapat menjadikan pembaca memiliki posisi yang tegas dalam memaknai yang ada sebagai dasar realitas, seperti: apakah realitas itu bersifat tunggal atau jamak?; apakah realitas itu bersifat rohani atau jasmani?; serta beberapa pertanyaan tentang realitas yang lain. Pemikiran metafisika
Anton Bakker tersebut dianggap dapat mengerucutkan konsep tari sintren secara metafisi.

Penelitian ini bertujuan untuk: (1) mendeskripsikan pengetahuan mengenai Sintren secara menyeluruh seperti pengertian, bagian-bagian, mitologi, sejarah, bentuk, konsep dari tarian Sintren; (2) menjelaskan jawaban Anton Baker terhadap persoalan metafisika serta analisis terhadap konsep Tarian Sintren; dan (3) menganalisis konsep Tarian Sintren dalam metafisika Anton Baker untuk kehidupan sehari-hari.

\section{METODE}

Penelitian ini bersifat kualitatif dengan pengambilan data yang dilakukan melalui studi pustaka. Studi pustaka digunakan untuk memperoleh data tentang konsep Kesenian Sintren di Wilayah Jawa Tengah.

Data primer meliputi: (1) Revitalisasi Kesenian Sintren karya Atik Triratnawati Tahun 2012 yang diterbitkan oleh Balai Pelestarian Nilai Budaya (BPNB) Yogyakarta. (2) Pengantar Metafisika (Terjemahan Cuk Ananta Wijaya dengan judul asli Problem of Metaphysics) karya Frederic Sontag Tahun 2002 yang diterbitkan oleh Pustaka Pelajar Yogyakarta. (3) Ontologi Metafisika Umum karya Anton Bakker Tahun 1992 yang diterbitkan oleh Kanisius Yogyakarta.

Data sekunder meliputi beberapa buku yang bersifat melengkapi dan menunjang penelitian ini.

Tahapan pelaksanaan penelitian ini adalah sebagai berikut: (1) inventarisasi data yaitu mengumpulkan data yang berhubungan dengan penelitian. (2) Klasifikasi data yaitu memilih data yang telah diperoleh menjadi data primer dan sekunder. (3) Analisis yaitu menganalisis semua data yang ada baik data primer 
maupun data sekunder dengan metode penelitian yang digunakan.

\section{HASIL DAN PEMBAHASAN Kesenian Sintren}

Kesenian sintren secara etimologi berasal dari kata sintren yang terdiri dari dua suku kata, yaitu "si" dan "tren". Si mempunyai arti "dia" dan tren sendiri merupakan suatu panggilan untuk orang putri. Sintren dapat juga diartikan menjadi "si dia seorang putri". Kesenian ini merupakan kesenian yang ada pada pantura (pantai utara) Jawa, terutama daerah Jawa Tengah,dan Jawa Barat. Selain itu sintren juga menunjukkan pada pameran utama pada kesenian itu, yaitu seorang putri yang bertindak sebagai penari utama dalam kesenian itu.

Sintren sebagai sebuah bentuk seni pertunjukan rakyat di pantai utawa Jawa Tengah dan Jawa Barat pernah menjadi satu seni hiburan yang sangat digemari oleh masyarakat antara tahun 1950 sanpai 1963. Namun karena situasi politik yang melanda indonesia pada tahun 1966, sintren mengalami keterpurukan karena dianggap'racun yang melemahkan semangat revolusioner' dan mengalami kembali kejayaannya pada tahun 1990-an.

Kesenian sintren dapat dikatakan sebagai tarian mistis. Hal itu dikarenakan dalam pementasannya, kesenian sintren melalui ritual pemanggilan roh atau bidadari maupun pertunjukannya banyak bernuansa ritual magis. Dan seorang penarinya pun merasa dirasuki oleh sesok yang dikatakan roh atau bidadari.

Asal mula munculnya kesenian ini, tidak terlepas dari sebuah cerita yang melatar belakangi kesenian ini. Namun, ada dua versi berbeda yang menceritakan asal mula sintren. Versi yang pertama, menceritakan tentang kisah percintaan Ki Joko Bahu (Bahurekso) dengan
Rantamsari, yang tidak disetujui oleh Sultan Agung Raja Mataram. Untuk memisahkan cinta keduanya, Sultan Agung memerintahkan Bahurekso menyerang VOC di Batavia. Bahurekso melaksanakan titah Raja berangkat ke Batavia dengan menggunakan perahu Kaladita (Kala-Adi-Duta). Saat berpisah dengan Rantamsari itulah, Bahurekso memberikan sapu tangan sebagai tanda cinta.

Tak lama terdengar kabar bahwa Bahurekso gugur dalam medan peperangan, sehingga Rantamsari begitu sedih mendengar orang yang dicintai dan dikasihi sudah mati. Terdorong rasa cintanya yang begitu besar dan tulus, maka Rantamsari berusaha melacak jejak gugurnya Bahurekso. Melalui perjalan sepanjang wilayah pantai utara Rantamsari menyamar menjadi seorang penari sintren dengan nama Dewi Sulasih. Dengan bantuan sapu tangan pemberian Ki Bahurekso akhirnya Dewi Rantamsari dapat bertemu Ki Bahurekso yang sebenarnya masih hidup.

Karena kegagalan Bahurekso menyerang Batavia dan pasukannya banyak yang gugur, maka Bahurekso tidak berani kembali ke Mataram, melainkan pulang ke Pekalongan bersama Dewi Rantamsari dengan maksud melanjutkan pertapaannya untuk menambah kesaktian dan kekuatannya guna menyerang Batavia lain waktu. Sejak itu Dewi Rantamsari dapat hidup bersama dengan Ki Bahurekso hingga akhir hayatnya.

Versi yang kedua menceritakan tentang Sulasih dan R. Sulandono seorang putra Bupati di Mataram Joko Bahu atau dikenal dengan nama Bahurekso dan Rr. Rantamsari. Percintaan Sulasih dan R. Sulandono tidak direstui oleh orang tua R. Sulandono. Sehingga R. Sulandono diperintahkan ibundanya untuk bertapa 
dan diberikan selembar kain ("sapu tangan") sebagai sarana kelak untuk bertemu dengan Sulasih setelah masa bertapanya selesai. Sedangkan Sulasih diperintahkan untuk menjadi penari pada setiap acara bersih desa diadakan sebagai syarat dapat bertemu R. Sulandono.

Tepat pada saat bulan purnama diadakan upacara bersih desa diadakan berbagai pertunjukan rakyat, pada saat itulah Sulasih menari sebagai bagian pertunjukan, dan R. Sulandono turun dari pertapaannya secara sembunyi-sembunyi dengan membawa sapu tangan pemberian ibunya. Sulasih yang menari kemudian dimasuki kekuatan spirit Rr. Rantamsari sehingga mengalami "trance" dan saat itu pula R. Sulandono melemparkan sapu tangannya sehingga Sulasih pingsan. Saat sulasih "trance/kemasukan roh halus/ kesurupan" ini yang disebut "Sintren", dan pada saat R. Sulandono melempar sapu tangannya disebut sebagai "balangan". Dengan ilmu yang dimiliki R. Sulandono maka Sulasih akhirnya dapat dibawa kabur dan keduanya dapat mewujudkan cita-citanya untuk bersatu dalam mahligai perkawinan.

Untuk menjadi seorang sintren, persyaratan yang utama adalah penari diharuskan masih gadis dan perawan. Hal ini dikarenakan seorang sintren harus dalam keadaan suci dan penari sintren merupakan "bidadari" dalam pertunjukan. Bahkan sebelum menjadi seorang sintren sang gadis diharuskan berpuasa terlebih dahulu, hal ini dimaksudkan agar tubuh si gadis tetap dalam keadaan suci. Karena dengan berpuasa otomatis si gadis akan menjaga pola makannya, selain itu dia akan menjaga tingkah lakunya agar tidak berbuat dosa dan berzina. Sehingga tidak menyulitkan bagi roh atau dewa yang akan masuk ke dalam tubuhnya.
Ada beberapa istilah dalam kesenian sintren. Yang pertama adalah paripurna. Yaitu tahapan menjadikan sintren yang dilakukan oleh Pawang, dengan membawa calon penari sintren bersama dengan 4 (empat) orang pemain. Dayang sebagai lambang bidadari (Jawa: Widodari patang puluh) sebagai cantriknya Sintren. Kemudian Sintren didudukkan oleh Pawang dalam keadaan berpakain biasa dan didampingi para dayang/cantrik.

Dalam paripurna, pawang segera menjadikan penari sintren melalui tiga tahap.

Tahap pertama, pawang memegang kedua tangan calon penari sintren, kemudian diletakkan di atas asap kemenyan sambil mengucapkan mantra, selanjutnya calon penari sintren diikat dengan tali yang dililitakan ke seluruh tubuh.

Tahap kedua, calon penari sintren dimasukkan ke dalam sangkar (kurungan) ayam bersama busana sintren dan perlengkapan merias wajah. Beberapa saat kemudian kurungan dibuka, sintren sudah berdandan dalam keadaan terikat tali, lalu sintren ditutup kurungan kembali.

Tahap ketiga, setelah ada tanda-tanda sintren sudah jadi (biasanya ditandai kurungan bergetar/bergoyang) kurungan dibuka, sintren sudah lepas dari ikatan tali dan siap menari. Selain menari adakalanya sintren melakukan akrobatik diantaranya ada yang berdiri diatas kurungan sambil menari. Selama pertunjukan sintren berlangsung, pembakaran kemenyan tidak boleh berhenti.

Istilah yang kedua adalah balangan (Jawa: mbalang). Balangan yaitu pada saat penari sintren sedang menari maka dari arah penonton ada yang melempar sesuatu ke arah penari sintren. Setiap penari terkena lemparan maka sintren akan jatuh pingsan. Pada saat itu, pawang 
dengan menggunakan mantra-mantra tertentu kedua tangan penari sintren diasapi dengan kemenyan dan diteruskan dengan mengusap wajah penari sintren dengan tujuan agar roh bidadari datang lagi sehingga penari sintren dapat melanjutkan menari lagi. Kemudian, penonton yang melemparkan uang tersebut diperbolehkan untuk menari dengan sintren. Kemudian yang terakhir adalah istilah temohan. Temohan adalah penari sintren dengan nyiru/tampah atau nampan mendekati penonton untuk meminta tanda terima kasih berupa uang ala kadarnya.

Sebelum memulai pertunjukan, maka akan dilakukan Dupan. Dupan yaitu acara berdoa bersama-sama diiringi membakar kemenyan dengan tujuan memohon perlindungan kepada Tuhan Yang Maha Esa agar selama pertunjukan terhindar dari mara bahaya.

Pertunjukan dimulai saat gamelan ditabuh sebagai tanda akan dimulainya pertunjukan kesenian sintren dan dimaksudkan untuk mengumpulkan massa atau penonton. Kemudian, juru kawih akan membacakan mantra-mantra, "tambak tambak pawon. Isie dandang kukusan. Ari kebul-kebul wong nontone pada kumpul". Mantra ini untuk memanggil penonton, juru kawih tidak akan berenti membacakan mantra tersebut hingga penonton kumpul.

Kemudian saat sintren akan dimasukkan roh. Biasanya roh yang diundang adalah roh Dewi Lanjar, jika sang Dewi Lanjar, maka penari akan terlihat lebih cantik dan membawakan tarian dengan cantik dan mempesona. Mantra yang biasa dinyanyikan untuk memanggil Dewi Lanjar agar masuk ke dalam tubuh penari adalah "nemu kembang yona yoni, kembange siti mahendra, widadari temurunan, merasuki badan nira". Kemudian setelah roh sudah masuk ke dalam tubuh penari, maka kurungan akan dibuka. Kemudian juru kawih membacakan syair selanjutnya "kembang trate, dituku disebrang kana, kartini dirante, kang rante aran man grana". Maka munculah penari sintren yang sudah cantik jelita.

Tempat yang digunakan untuk pertunjukan kesenian sintren adalah arena terbuka. Hal ini di maksudkan agar pertunjukan yang sedang berlangsung tidak terlihat batas antara penonton dengan penari sintren maupun pendukungnya. Pertunjukan sintren ini umunya lebih komunikatif, artinya ada interaksi antara pemain dengan penonton. Bisa dibuktikan pada saat acara balangan dan temohan, dimana antara penonton dan penari sintren terlihat menyatu dalam satu pertunjukan dengan ikut menari setelah penonton melakukan balangan pada penari sintren. Sintren yang menari biasanya didampingi dengan penari pendamping dan seorang bodor atau pelawak.

Lagu-lagu yang dimainkan biasanya lagu jawa. Alat music yang digunakan, awalnya merupakan alat yang sederhana. Seperti, gending dan alat yang menyerupai dandang dan nampah, namun tetap asik untuk didengarkan. Berbeda dengan sekarang, alat music yang digunakan menggunakan orkes. Mungkin hal ini dilakukan untuk mengikuti perkembangan zaman dan menarik banyak perhatian orang untuk menyaksikan pertunjukan sintren.

Busana yang digunakan penari sintren dulunya berupa pakaian kebaya (untuk atasan). Busana kebaya ini lebih banyak dipakai oleh wanita yang hidup di desadesa sebagai busana keseharian. Sekarang ini penari sintren umumnya menggunakan busana golek yang lebih nyentrik.

Pertama, tata cara penyajian/ panggung. Tarian diselenggarakan di tempat yang sunyi pada malam bulan 
purnama dan hari pasarannya Kliwon lebih-lebih malam Jumat Kliwon.

Urutan penyajian dibagi tiga tahap yaitu tahap pra pertunjukan/persiapan, tahap pertunjukan, dan tahap paripurna/ penyadaran.

Kedua, perlengkapan. Seperangkat instru-men, tetekan adalah suatu alat yang di gunakan untuk mengiringi ritme dan melodi penarinya. Sesajian yang disiapkan adalah bunga melati, anglo padupan, arang, kemenyan putih, korek api, bunga telon, rokok siong, jaran gribig, penutup kurungan, dan nampan.

Seperangkat pakaian dan kelengkapan rias yaitu (1) baju keseharian, yang dipakai sebelum pertunjukan kesenian sintren berlangsung, (2) baju golek adalah baju tanpa lengan yang biasa dipergunakan dalam tari golek, (3) kain atau jarit model busana wanita Jawa, (4) celana cinde, yaitu celana tiga perempat yang panjangnya hanya sampai lutut, (5) sabuk yaitu berupa sabuk lebar dari bahan kain yang biasa dipakai untuk mengikat sampur, (6) sampur, berjumlah sehelai/selembar dililitkan di pinggang dan diletakkan di samping kiri dan kanan kemudian ditutup sabuk atau diletakkan di depan, (7) jamang, adalah hiasan yang dipakai dikepala dengan untaian bunga melati di samping kanan dan kiri telinga sebagai koncer, (8) kaos kaki hitam dan putih, seperti ciri khas kesenian tradisional lain khususnya di Jateng, dan (9) kacamata hitam, berfungsi sebagai penutup mata karena selama menari, sintren selalu memejamkan mata akibat kerasukan "trance", juga sebagai ciri khas kesenian sintren dan menambah daya tarik/mempercantik penampilan

Ketiga, gerakan atau tari, musik, dan nyanyian atau tembangnya.

Pertunjukan sintren awalnya disajikan pada waktu sunyi dalam malam bulan purnama dan menurut kepercayaan masyarakat lebih utama lagi kalau dipentaskan pada malam kliwon, karena di dalam kesenian sintren terdapat ritual dan gerakan yang sangat berkaitan dengan kepercayaan adanya roh halus yang menjelma menjadi satu dengan penari sintren.

Seni sintren mengandung nilai-nilai sebagai berikut. Pertama, nilai religuis. Pertunjukan sintren merupakan budaya pra-islam yang masih menggunakan mantra dan mengundang roh halus tersebut dilakukan oleh masyarakat Pekalongan untuk bersih desa atau memohon hujan. Dengan kepercayaan penuh mereka yakin bahwa permohonan hujan agar segera turun. Mereka yakin bahwa permohonan mereka kepada Tuhan Yang Maha Esa lewat pertunjukan sintren akan terkabul. Nilai religius nampak pada ritual dan syairnya. Pengucapan bismillah dalam mengawali pertunjukan sintren sebgai bukti konkrit pengakuan terhadap adanya Tuhan Yang Maha Esa, Allah SWT.

Kedua, nilai sosial. Sintren dapat memberikan kegiatan positif berupa latihan-latihan misalnya tari, iringan,syair dan sebagainya. Dengan mengadakan latihan maka akan tumbuh rasa kekeluargaan dan gotong royong yang kuat. Jika sudah demikianmaka tumbuh pula gairah untuk membangun wilayahnya serta menjadikan yang baik, menyenangkan sehingga hidup mereka tenang dan menyenangkan. Melalui sintren dalam adegan badoran atau bodoran pun dapat dimanfaatkan untuk menyampaikan secara menghibur. Konsep ini akan lebih efektif dan lebih mudah dicerna oleh penonton. Bahkan tidak hanya dalam bodoran saja, mungkin saja diciptakan lagu-lagu yang memuat pesan sosial tanpa kehilangan ruh seni sintren. 
Ketiga, nilai keamanan. Pada kehidupan di Dusun Blimbing, meskipun listrik sudah masuk namun kalau sudah senja maka suasana menjadi sunyi. Kondisi itu akan berubah jika ada latihan sintren maupun pertunjukan sintren menjadi lebih hidup. Banyak warga yang ikut melihat sehigga hal ini dapat membuat mereka pergi tidur agak malam dan keamanan menjadi lebih meningkat.

Keempat, nilai seni. Seni sintren mengandung nilai seni sastra, seni tari, tata rias, seni busana, dan seni dekorasi. Kelima hal tersebut dijelaskan sebagai berikut.

Seni sastra. Pada tembang-tembang yang dinyanyikan hampir setiap daerah memiliki kekhasannya masing-masing. Kondisi itu membuat peluang kepada pada juru kawi rajin berlatih dan rajin mengadakan ungkapan-ungkapan spontanitas, akan mampu menyusun kata-kata dan kalimat-kalimat baru yang lebih indah, disamping itu juga akan tercipta syair baru yang mengandung isi serta bentuk syair yang lebih indah. Tentu saja bahasa sintren pekalongan akan memiliki bentuk sastra tersendiri yang akan berbeda dengan bentuk-bentuk sastra yang digunakan dalam pergualan sehari-hari. Dengan kreasi serta inovasi baru dalam syairnya bukan tidak mungkin seni sintren akan menjadi sebuah hiburan yang menarik sebuah hiburan yang menarik bagi penontonya.

Seni Tari. Sintren garapan, unsur tari menjadi lebih penting lagi. Hal itu tampak pada penataan serta pola tari yang sudah dirancang sedemikian rupa dengan memerhatikan gerakan, kostum, dan juga alur cerita yang digambarkanya. Sebagaimana di dalam adegan pedesaan seorang sintren yang bernama Sulasih datang dengan pakaian/kostum busana yang masih sederhana dengan diiringi para penari bedaya dari kehayangan. Setelah itu melalui berbagai tahapan yang ada, sintren memakai busana yang inah bagaikan bidadari. Tarian dalam sebuah sintren garapan sangat menonjol karena memang dipersiapkan dan dipolakan sesui adegan dan alur cerita.

Tata rias. Selain sintren tata rias atau make up seorang bador yang berperan sebagai komedian juga penting untuk menghidupkan pertunjukan sintren. Kondisi tersebut tampak dari sintren garapan. Sebagai sebuah sintren garapan lebih menonjolkan nilai seni yang menghibur maka make up merupakan unsur yang sangat penting, dengan bermake up kekurangan fisik dapat ditutup dengan make up ini.

Seni busana. Pakaian penari diusahakan busana yang berbeda dan menambah kecantikan, busana bodor yang mampu menambah kegagahannya, namun diharapkan ada unsur kelucuan, para juru kawiyang berbusana kebaya dan kain, sedang para penabuh pria berpakaian ikat kepala, baju komprang dan celana komprang. Maka dari itu dalam kesenian sintren brebes ini dalam busananya memiliki peranan yang sangat penting pula.

Seni dekorasi. Setelah muncul sintren garapan maka unsur dekorasi ada, hal itu tampak pada penggarapan poperti yang digunakan serta berbagai pernik panggung atau lantai yang digunakan sebagai arena pertunjukan. Sebagai contoh, dalam sintren garapan divisualisasikan sampah atau dedaunan yang berada di arena pertunjukan untuk memunculkan kesan desa. Bahkan di tambah dengan tata lampu yang memvisualisasikan latar cerita.

Kelima, hiburan. Kehadiran kesenian sintren pekalongan ini kembali di tengahtengah masyarakat di pedesaan tersebut akan mempunyai nilai hiburan tersendiri 
yang cukup tinggi di tengah-tengah banyak hiburan yang lain yang lebih modern. Munculnya sintren garapan juga smeakin menambah khasanah pertujukan sintren sebagai seni yang menghibur. Unsur-unsur-unsur baru dalam kesenian sintren garapan yang mempunyai nilai keindahan merupakan sesuatu yang menghibur, seperti alur cerita yang jelas, gerakan tari, tata panggung, penari latar maupun poperti lain dapat menyuguhkan hiburan tersendiri dalam sintren garapan.

Kelima, ekonomi. Ketika kesenian sintren di kota pekalongan mengalami kejayaan maka banyak sekali bermunculan kelompok sintren namun setelah sepi tanggapan maka keberadaannya kini hampir punah. Pada jaman dulu memperoleh uang dari hasil tanggapan serta temongan dari penonton, namun sekarang dengan sepinya tanggapan maka uang sering diperoleh hanya dari tanggapan saja.

Keberadaan kesenian sintren di kota pekalongan maupun kabupaten pekalongan saatinisangatmemprihatinkan. Kesenian sintren yang dahulu pernah mencapai kejayaan dan menjadi ikon di dua pemerintahan daerah itu secara perlahan mulai mengalami kemunduran dan bahkan menuju kepunahan jika tidak di lakukan langkah-langkah upaya pelestarian. Sebagai mana berikut langkahlangkah pelestarian yaitu dengan (1) mempertahankan keberadaan budaya tersebut, (2) mengembangkan budaya yang sudah ada itu, dan (3) kemudian memanfaatkan budaya itu sendiri. Dan ada beberapa upaya yang dilakukan pemerintah yaitu melalui masyarakat sendiri(intern) maupun dari pemerintah (ekstern).

Upaya secara intern sebagai berikut.

(1) Latihan. Dengan diadakannya latihan tersebut, secara tidak langsung mengenalkan kembali sintren terhadap generasi muda dan warga masyarakat lainnya yang sudah lupa. Latihan tersebut juga upaya agar si pelaku seni pertunjukan itu tidak lupa irama gamelan, lagu yang dinyanyikan, tahap-tahap pelaksanan maupun mantra-mantra sang pawang. (2) Sarana-prasarana. Dengan perkembangan jaman di era sekarang sarana-prasaran penunjang kesenian sintren pun ikut berkembang. Dahulu alat pengiring pertujukan tersebut hanya menggunakan seperangkat gamelan slendro, sekarang sudah di tambah atau dilengkapi dengan sebuah organ dan juga gitar listrik. Selain itu juga seni jaran kepang(kuda lumping).

Upaya secara ekstern sebagai berikut. (1) Wujud pelestarian dengan membawa kesenian sintren asli atau tradisional pada even-even tertentu yang memungkinkan untuk dilakukan. (2) Bantuan berupa seperangkat alat gamelan, karena bantuan berupa sepangkon (slendro dan pelog) maka untuk sementara dialihkan agar fungsinya lebih maksimal. (3) Memberikan sanggar atau gedung sanggar budaya untuk menunjang aktivitas seni di Kota Pekalongan. (4) Pengembangan sintren ke sintren garapan yang di rasa lebih menarik untuk ditonton.

\section{Metafisika Umum Anton Bakker}

Anton Bakker lahir di Kota Amsterdam, Negeri Belanda pada tanggal 20 Desember 1931. Bakker merupakan putra dari pasangan Henricus Jacobus dan Catharina Bakker. Anton Bakker atau yang lebih sering disapa dengan Romo Bakker memiliki nama lengkap Antonius Henricus Bakker, SJ. 22

Anton Bakker sebelum masuk Serikat Yesuit, menempuh pendidikannya terlebih dahulu di Kolese St. Ignatius, Amsterdam. Tahun 1950 pada saat berusia 19 tahun, 
Bakker memasuki tahun pertama novisiat di Meniendal, Nijmegen hingga tahun 1951. Perjalanan Bakker di Indonesia di mulai pada tanggal 13 September 1951 dalam rangka menjalani tahun kedua novisiatnya di Giri Sonta, Semarang. Tanggal 18 September 1952, Anton Bakker menjalani yuniorat selama dua tahun di tempat yang sama, yaitu Giri Sonta.

Tahun 1954, Anton Bakker pergi ke Kolese Ignatius, Yogyakarta untuk belajar filsafat. Pendidikan tersebut diselesaikan Anton Bakker pada tahun 1975 dengan mendapatkan gelar Licenciat dan kemudian dilanjutkan dengan tahun Orientasi Karya di Seminari Menengah Mertoyudan hingga tahun 1960. Anton Bakker kemabali lagi ke Kolese Ignatius, Yogyakarta pada tahun yang sama untuk melanjutkan pendidikan teologi.

Tanggal 31 Juli 1963 adalah tahun yang bersejarah bagi Anton Bakker, karena saat itu Bakker ditasbihkan menjadi Imam Katolik. Anton Bakker tinggal di Kolese hingga tahun 1964 dan berhasil mendapatkan gelar Licenciat teologi. Lantas Anton Bakker melanjutkan pendidikan filsafatnya di Fakultas Berchmanianum, Negeri Belanda dan mendapatkan gelar doktor filsafat pada tahun 1967.

Metafisika sebagai sautu disiplin ilmu filsafat memiliki objek material yang-ada, atau dalam bahasa sederhananya adalah hakikat realitas. Membahas tentang hakikat realitas, tidaklah dapat dipisahkan dengan pembahasan tentang hakikat pengada, baik pengada Yang Hakiki (Tuhan) maupun pengada nonhakiki (ciptaan-Nya). Membahas tentang pengada yang hakiki, pertama-tama perlulah memahami dahulu hakikat pengada yang lain, dalam penelitian ini pengada yang lain difokuskan kepada manusia. Pandangan manusia sebagai pengada akan menentukan pula kepada hakikat pengada yang lain, hingga akhirnya sampai pada pembicaraan tentang Pengada Yang Hakiki, yaitu Tuhan. Anton Bakker secara khusus membicarakan pengada-pengada tersebut melalui beberapa pertanyaan berikut.

Pertama, otonomi dan korelasi; kebanyakan dan kesatuan (kuantitas realitas). Kuantitas memiliki 'tempat' tersendiri dalam pembahasan ontologi karena sifatnya dapat menegaskan apakah yang hakiki itu berjumlah satu atau banyak. Anton Bakker turut menyatakan bahwa persoalan kuantitas merupakan pertanyaan ontologi yang paling fundamental karena menentukan sudut pandang mengenai kenyataan seutuhnya dan memberikan arah utama bagi seluruh ontologi (Bakker dalam Ardiansyah, 2012: 33).

Anton Bakker merumuskan permasalahan kuantitas tersebut melalui sejumlah pertanyaan, yaitu "apakah keseluruhan kenyataan bersifat tunggal atau majemuk? Apakah keseluruhan kenyataan seragam atau beranekaragam dan apakah kenyataan sama sekali tidak mempunyai satu kesatuan dan justru terpecah-pecah?". Permasalahan kuantitas tersebut berkerucut pada pembahasan realitas sebagai salah satu objek kajian ontologi. Satu hal yang perlu diperhatikan adalah realitas dalam penjabaran ini dimaksudkan untuk Tuhan sebagai Realitas Tertinggi serta manusia sebagai bagian dari realitas itu. (Ardiansyah, 2012: 33)

Peneliti berusaha memaparkan penjelasan Bakker terkait kemungkinan dari kuantitas realitas yang permasalahannya telah di jabarkan diatas. Terkait permasalahan "apakah kenyataan bersifat tunggal atau majemuk", Anton Bakker menjelaskan hal tersebut dengan menjabarkan beberapa implikasi, yaitu 
jika kenyataan itu bersifat tunggal maka akan sangat susah mengahadapi pemahaman orang awam bahwa ada banyak objek. Hal tersebut dapat dipahami karena kecenderungan orang biasa yang memang memandang jasmani sebagai gambaran realitas, sehingga hal yang kasat mata serig tidak diperhatikan karena kuasa benda yang nyata tersebut. Hal sebaliknya, jika kenyataan itu bersifat majemuk atau banyak, maka akan berhadapan dengan pertanyaan "apakah yang banyak saling berhubungan satu sama lain atau kenyataan tersebut justru berdiri sendiri ataukah mungkin kenyataan sama sekali tidak mempunyai satu kesatuan dan terpecah-pecah" (Bakker dalam Ardiansyah, 2012: 34).

Anton Bakker sendiri menjawab permasalahan kuantitas realitas dengan berargumen bahwa setiap pengada selalu bersifat otonom dalam korelasi (Bakker dalam Ardiansyah 2012: 36). Pengada akan menemukan keotonomian ketika berada dalam korelasi dengan pengada lainnya. Argumen itu bisa dianalogikan seperti seorang dosen dengan mahasiswanya. Dosen mustahil menjadi dosen apabila tidak ada mahasiswa, sedangkan mahasiswa mustahil menjadi mahasiswa apabila tidak ada guru. Keotonomian seorang dosen terletak pada relasinya terhadap mahasiswa dan keotonomian mahasiswa terletak dalam relasi kepada gurunya. Berdasarkan analogi tersebut, maka jelas bahwa setiap pengada bersifat otonom sekaligus berkorelasi. Otonomnya setiap pengada menandakan bahwa pengada itu bersifat pluralis karena terdiri dari beranekaragam dan realsinya dari setiap pengada menandakan bahwa pengadapengada tersebut terangkum dalam satu kesatuan yang harmonis dan tidak dapat dipisahkan lagi (Ardiansyah, 2012: 36).
Kedua, sifat pengada. Pembahasan tentang kuantitas realitas berefek pada pembahasan ontologi yang lain, yaitu sifat pengada. Pengada yang dimaksudkan disini adalah pengada yang hakiki, yaitu Tuhan serta pengada yang mengadakan dirinya sendiri atau manusia. "Sifat" sendiri banyak diartikan sebagai sesuatu yang menempel pada objek dan dapat menentukan karakter baik-buruknya objek tersebut (Ardiansyah, 2012: 36).

Bakker merumuskan persoalan sifat pengada dengan memberikan dua pendangan aliran yang tidak sama. Aliran yang pertama menganggap bahwa setiap pengada memiliki kesamaan sifat dalam pengada-pengada yang berbeda. Aliran yang kedua menganggap bahwa setiap pengada memiliki banyak macam sifat yang tidak sama (Bakker, 1992: 57-59).

Anton Bakker dalam menyelesaikan persoalan sifat pengada tidak terlepas dari persoalan tentang kuantitas pengada, bahwa otonomi dan korelasi merupakan satu hal hakiki bagi setiap pengada atau sifat khas ontologies (Bakker, 1992: 63). Ciri-ciri hakiki tersebut bercorak transendental artinya tidak terbatas pada salah satu atau beberapa pengada tertentu melainkan mengatasi semunya. Sifat ini berlaku pada setiap pengada sampai pada taraf Tuhan juga.

Pengada selain mempunyai sifat transendental, juga mempunyai sifat kategorikal. Anton Bakker menyatakan bahwa masih terdapat sifat nyata bukan transendental yaitu sifat seperti berperilaku secara khusus bagi setiap taraf pengada (Bakker, 1992: 65). Sifat inilah yang tergolong dalam sifat kategorikal, maka Bakker menyelesaikan persoalan mengenai sifat pengada dengan bahasa "transendental dan kategorikal".

Ketiga, dinamika pengada. Istilah 'dinamika' identik dengan kata 
'berubah' kata yang selalu sejalan dengan pertanyaan, "apakah tetap (tidak berubah) atau berubah?". Kata dinamika dapat menunjukkan dua hal, yaitu statis dan dinamis. Statis apabila subjek tersebut permanen atau tidak mengalami perubahan dan tidak berproses, sedangkan dinamis apabila subjek tersebut mengalami proses, baik lahir dan berkembang. Penjelasan tentang dinamika harus dilihat dahulu hakikat pengada dari pengada tersebut, apakah pengada itu memuat aspek Yang Hakiki, yaitu Tuhan atau pengada tersebut hanya sebatas pengada yang diadakan atau pengada nonhakiki. Penjelasan ini dititikberatkan pada persoalan dinamika pengada sebagai Yang Hakiki, namun untuk sampai ke persoalan itu haruslah dicari juga pengada yang lain, seperti manusia, batu, tumbuhan dan lain-lain. Penjelasan ini lebih memfokuskan pada manusia sebagai wakil dari realitas nonhakiki tersebut (Ardiansyah, 2012: 39)

Keempat, kejasmanian dan kerohanian (kualitas realitas). Pemakaian istilah 'kualitas' pada dasarnya bukanlah merujuk kepada sifat yang dimiliki oleh satu pengada seperti penyayang, pemberi, dan sebagainya. Kualitas dalam penjelasan ini lebih diarahkan kepada satu bentuk yang ada dalam pengada itu. Kualitas dalam penjelasan ini akan diidentikkan dengan kata 'rohani' dan 'jasmani'. Rohani adalah sebuah kualitas yang didasarkan atas sifat kerohanian, sifatnya tidak tampak (abstrak), sedangkan jasmani adalah kualitas yang terkait dengan dengan bentuk, ukuran dan beberapa hal yang dianggap tampak (Ardiansyah, 2012: 42)

Sejalan dengan perkembangan filsafat telah ditemukan beberapa filosof yang berperan sebagai peletak dasar, bahwa kenyataan itu bersifat rohani dan ada juga beberapa filsuf yang meyakini bahwa kenyataan hanya sebatas jasmani. Hal ini maksudnya adalah segenap kenyataan berpotensi untuk bersifat rohani atau sekaligus bersifat rohani. Perseturuan antara rohani dan jasmani itu ditengahi oleh pihak dualisme. Dualisme menekankan bahwa kualitas pengada itu senantiasa terbagi menjadi dua, yaitu rohaniah dan jasmaniah yang memiliki kedudukan tidak sama: rohaniah diletakkan di atas, yaitu Tuhan dan jasmaniah diletakkan di bawah, yaitu segala bentuk materi di dunia. Perkembangan sejarah terkadang menjunjung tinggi salah satu dari dua unsur tersebut. Beberapa kalangan mengatakan bahwa badan membatasi jiwa, beberapa lagi meyakini bahwa badan adalah substansi yang nyata. (Ardiansyah, 2012: 41-45)

Kelima, kegiatan dan penyebaban. Istilah kegiatan dan penyebaban adalah kata yang sering dipakai untuk merujuk pada pembahasan tentang sebab-akibat. Kegiatan tidak lain adalah brntuk kata kerja yang menandakan adanya sebuah aksi, sedangkan penyebaban adalah kata yang selalu menyertai kata kerja itu yang berarti akibat. Penyebaban identic dengan bentuk kata kerja kausalitas (sebabakibat), sehingga dalam penjelasannya sudah pasti tidak akan jauh dari istilah implikasi. Penjelasan mengenai kegiatan dan penyebaban pengada erat kaitannya dengan bentuk hubungan pengada yang satu dengan pengada yang lainnya. (Ardiansyah, 2012: 45).

Penjelasan mengenai kegiatan dan penyebaban ini berbeda dengan dinamika pengada. Dinamika pengada hanya membahas sisi permanensi dan kebaharuan substansi pribadi secara intern, namun masalah kegiatan dan penyebaban lebih dititikberatkan pada penelitian tentang hubungan antara pengada-pengada; mempersoalkan akibat 
dan hasil kegiatan pengada yang satu di dalam pengada yang lainnya.

Keenam, arti dan nilai pengada. Kegiatan pengada dibedakan menjadi dua segi yang berlainan yaitu pengertian dan penghendakan. Pengertian pengada merupakan sesuatu yang mengarahkan pengada itu kepada arti dan penghendakan pengada merupakan sesuatu yang mengarahkan pengada kepada yang bernilai. Arti merupakan sesuatu yang mempunyai pengertian dan nilai adalah sesuatu yang disebabkan atas penghendakan. Arti dan nilai pengada berarti netral, belum menunnjukkan mana yang berarti benar atau palsu, atau mana yang bernilai baik atau buruk, tinggi atau rendah. Atas dasar hal itu, maka dipergunakan istilah 'arti' dan bukan 'makna', karena makna diberi pemahaman terlalu positif (Ardiansyah, 2012: 48).

Bakker memberikan jawaban mengenai arti dan nilai dapat dilihat dari 'tafsiran dan taksiran' dalam setiap kegiatan yang dilakukan pegada (Bakker dalam Ardiansyah 2012: 50). Tafsiran sendiri didefinisikan sebagai penerjemahan substansi pengada, sehingga mempunyai arti. Taksiran didefinisikan dengan memberikan nilai atas pengada itu. Tafsiran dan taksiran ini meliputi dua macam, yakni tafsiran imanen dan transenden serta taksiran imanen dan transenden. Imanen dan transenden ini didasarkan atas bentuk kegiatan setiap pengada yang meliputi kegiatan berkomunikasi dan berpartisipasi baik dengan diri sendiri maupun dengan yang lain.

Ketujuh, norma pengada. Norma identik dengan sesuatu yang memperlihatkan baik atau buruk. Perlu diperhatikan bahwa yang benar dan baik selalu menduduki tempat yang lebih tinggi daripada yang kurang benar dan kurang baik. Perbedaan antara kelebihan dan kekurangan ini pada dasarnya tidak hanya dipengaruhi oleh unsur struktural saja, melainkan juga ditentukan oleh cara menghayati secara pribadi atas unsur struktural itu. Unsur struktural dalam penjelasan mengenai kelebihan dan kekurangan itu merupakan bentuk penjelasan secara objektif, sedangkan cara menghayati secara pribadi unsur struktural bersifat subjektif (Ardiansyah, 2012: 51).

Bakker menjawab persoalan norma pengada dengan menerangkan 'kebenaran dan kebaikan' pengada. Setiap pengada menafsirkan dan menaksirkan dirinya dalam komunikasi dengan yang lain sesuai dengan penghayatan kemacamragaman bipolar itu. Berdasarkan hal itu, bipolaritas yang bermacam ragam menjadi landasan pemberartian dan pembernialaian dan sejauh hal itu ditentukan dan dipilih, sedangkan kebenaran dan kebaikan pengada ditentukan (Bakker, 1992: 205). Pengada sambil memberartikan dan membernilaikan diri, menghayati keselarasan maksimal dalam bipolaritas struktural, sehingga di dalamnya mengandung kebenaran dan kebaikan; Tuhan yang benar dan baik, manusia yang benar dan baik, hewan yang benar dan baik, namun dengan taraf dan tingkatan yang berbeda karena semuanya berbeda satu sama lain (Ardiansyah, 2012: 54)

Kedelapan, yang-tiada. Manusia selalu menerima pengingkaran dan penyangkalan. Salah satu bentuk pengingkar dan penyangkalan manusia adalah tentang ada dan tiada. Manusia dapat menyadari bahwa seseorang atau sesuatu pada dasarnya tidak ada. Hal ini dikarenakan manusia mampu memberikan tempat bagi pengingkaran. Manusia dapat meniadakan dan memusnahkan pengada- 
pengada, entah manusia lain, hewan atau pun tumbuhan (Bakker, 1992: 235).

Tiada bukanlah satu ruang dan waktu yang kosong, 'tiada kini dan tiada sini'. Bakker menjelaskan bahwa ruang dan waktu yang kosong itu hanya merupakan khayalan (Bakker, 1992: 242). Berdasarkan hal ini maka akan tampak bahwa tiada bukanlah sesuatu yang berdasarkan atas ruang dan waktu yang kosong. Tiada adalah tanpa ruang dan tanpa waktu. Tiada atau tepatnya bukan pengada merupakan bentuk tanpa ruang dan tanpa waktu karena tidak mengadanya. Hal itu berarti bukan pengada tersebut bukan otonom dan bukan korelasi, bukan aktif dan bukan pasif, bukan berarti dan bukan berniali, dan dengan sendirinya pengada itu tidak bisa benar-baik atau palsu-buruk. Dapat disimpulkan bahwa bukan pengada itu tidak lain hanya merupakan kekosongan segala sifat transendental sehingga bukan pengada tersebut tidak ada (Ardiansyah, 2012: 57).

Kesembilan, analogi. Kekhususan objek ontologi berakibat dalam persoalan pemakaian bahasa. Penelitian terhadap bahasa termasuk refleksi tentang pengetahuan manusia. Bahasa adalah bentuk penyampaian yang dilakukan oleh setiap pengada atas diri sendiri dan yang lain. Bahasa menjadi layak untuk dibahas karena menyangkut cara pengada dalam mengadakan dirinya. Perhatian yang pertama-tama yang akan diarahkan kepada pemakaian kata-kata atau konsepkonsep dalam ontologi (Ardiansyah, 2012: 58).

Bahasa dan pikiran merupakan satu kesatuan yang erat, karena dengan bahasa pikiran seseorang akan dapat tersampaikan. Bahasa dan pikiran sama halnya dengan kata dan konsep yang pada dasarnya saling berdiri sendiri, namun juga saling berkaitan satu sama lain. Kata hanya berupa kata sejau mempunyai arti dan kalau tidak berarti hanya akan menjadi bunyi belaka dan konsep harus selalu diungkapkan dengan kata (Bakker, 1992: 247). Ontologi mencoba membahas hubungan antara bahasa dan pikiran, sehingga secara khusus difokuskan kepada pembahasan mengenai analogi.

Bakker mencoba merumuskan persoalan analogi dengan mengutip pandangan dari beberapa tokoh sepanjang sejarah. Berbagai pandangan itu adalah 'arti univokal', 'arti ekuivokal', 'dualisme konsep: univocal dan ekuivokal' dan terakhir adalah 'arti analogal'. Arti univokal mempercayai bahwa konsep 'pengada' dan konsep sifatnya serta konsep yang lain dalam bahasa dan pikiran pada dasarnya memiliki arti sama saja bagi segala pengada (Bakker, 1992: 248). Pandangan yang kedua dari kalangan yang mempercayai adanya arti ekuivokal dengan berpendapat bahwa konsep 'pengada' dan konsep dasar sifatnya dalam bahasa dan pikiran pada dasarnya menunjukkan arti lain dan lain dari setiap pengada, sifat dan kegiatannya (Bakker, 1992: 253).

Pendapat lain dari kalangan dualisme konsep univokal dan ekuivokal. Kalangan ini mempercayai bahwa konsep dalam rangka dunia dan manusia khususnya sejauh material bersifat univokal dan jika dipergunakan dalam dimensi roh serta Tuhan maka akan menjadi ekuivokal (Bakker, 1992: 254). Pendapat terakhir dari kalangan yang mempercayai adanya arti analogal yang diwakili oleh pemikiran Thomas Aquinas. Thomas Aquinas menyatakan bahwa konsep 'pengada' sendiri dan konsep transendental lain bersifat analogal; menunukkan bahwa setiap pengada secara formal memiliki 'mengada' dan bersama dengannya beberapa sifat umum dengan caranya sendiri-sendiri (Bakker, 1992: 255). 
Menurut Bakker, konsep pengada bersifat analogal. Pendapat ini didasarkan atas anggapan bahwa pada dasarnya konsep pengada berusaha mengungkapkan masingmasing taraf menurut realitasnya dan menurut aspeknya. Setiap pengada memiliki mengada dalam komunikasi dan kebersamaan sehingga dengan konsep itu semua pengada ditangkap menurut timbal baliknya dalam hal mengada; berlaku bagi Tuhan, manusia, hewan, tumbuhan, tanah dan lain-lain (Bakker, 1992: 257). Berdasarkan hal ini dapat ditarik kesimpulan bahwa konsep 'pengada' adalah umum universal dan sama, yakni dalam hal mengada. Konsep 'pengada' juga memiliki konsep pengucapan dalam hal mengadanya menurut kemandirian dan perbedaannya. Setiap pengada diungkapkan menurut mengadanya yang serba pribadi (Bakker, 1992: 259).

\section{Konsep Kesenian Sintren Ditinjau dari Segi Metafisika Anton Bakker}

Berbagai penggambaran, baik tentang konsep kesenian sintren maupun model pemikiran Anton Bakker tentang persolan metafisika telah peneliti paparkan pada bab-bab sebelumnya. Penjelasan tentang konsep kesenian sintren dan model pemikiran Bakker tersebut pada bab sebelumnya masih bersifat 'terpisah' dan belum ada titik temu satu sama lain, sehingga analisis ini bertujuan untuk menemukan sisi metafisika dalam konsep kesenian sintren.

Persoalan kuantitas pada pembahasan realitas yang perlu diperhatikan adalah realitas dalam penjabaran ini dimaksudkan untuk Tuhan sebagai Realitas Tertinggi serta manusia sebagai bagian dari realitas itu. Dalam hal ini Kesenian sintren sebenarnya bisa dikatakan sebagai tarian mistis. Hal itu dikarenakan dalam pemetasannya kesenian sintren melalui ritual pemanggilan roh atau bidadari maupun pertunjukannya banyak bernuansa ritual magis. Kuantitas dalam realitas kesenian sintren memiliki realitas banyak, tetapi yang paling tinggi tetap satu yaitu Tuhan.

Ciri-ciri dari sifat hakiki tersebut bercorak transendental artinya tidak terbatas pada salah satu atau beberapa pengada tertentu melainkan mengatasi semunya. Dupan, yaitu acara berdoa bersama-sama diiringi membakar kemenyan dengan tujuan memohon perlindungan kepada Tuhan Yang Maha Esa agar selama pertunjukan terhindar dari mara bahaya. Hal ini dilakukan supaya sifat pengada tersebut melakukan tugasnya dengan baik.

Pengertian pengada merupakan sesuatu yang mengarahkan pengada itu kepada arti dan penghendakan pengada merupakan sesuatu yang mengarahkan pengada kepada yang bernilai. Dalam arti dan penghendakan yang benilai, kesenian sintren memiliki hal itu. Arti dan penghendakan yang bernilai terwujud dalam nilai religi. Mereka yakin bahwa permohonan mereka kepada Tuhan Yang Maha Esa lewat pertunjukan sintren akan terkabul. Nilai religius nampak pada ritual dan syairnya. Pengucapan bismillah dalam mengawali pertunjukan sintren sebgai bukti konkrit pengakuan terhadap adanya Tuhan Yang Maha Esa, Allah SWT.

Kekhususan objek ontologi berakibat dalam persoalan pemakaian bahasa. Penelitian terhadap bahasa termasuk refleksi tentang pengetahuan manusia. Bahasa adalah bentuk penyampaian yang dilakukan oleh setiap pengada atas diri sendiri dan yang lain. Penyampaian bahasa ini dalam kesenian sintren sangat 
berpengaruh untuk jalannya pertunjukkan. Karena menurut kepercayaan, masyarakat lebih utama lagi kalau dipentaskan pada malam kliwon, karena di dalam kesenian sintren terdapat ritual dan gerakan yang sangat berkaitan dengan kepercayaan adanya roh halus yang menjelma menjadi satu dengan penari sintren.

\section{SIMPULAN}

Sintren sebagai sebuah bentuk seni pertunjukan rakyat di pantai utawa Jawa Tengah dan Jawa Barat. Asal mula munculnya kesenian ini, tidak terlepas dari sebuah cerita yang melatar belakangi kesenian ini. Ada beberapa istilah dalam kesenian sintren. Yang pertama adalah paripurna. Yaitu tahapan menjadikan sintren yang dilakukan oleh Pawang, dengan membawa calon penari sintren bersama dengan 4 (empat) orang pemain. Istilah yang kedua adalah balangan (Jawa : mbalang). Balangan yaitu pada saat penari sintren sedang menari maka dari arah penonton ada yang melempar sesuatu ke arah penari sintren. Yang terakhir adalah istilah temohan. Temohan adalah penari sintren dengan nyiru/tampah atau nampan mendekati penonton untuk meminta tanda terima kasih berupa uang ala kadarnya.

Tempat yang digunakan untuk pertunjukan kesenian sintren adalah arena terbuka. Hal ini di maksudkan agar pertunjukan yang sedang berlangsung tidak terlihat batas antara penonton dengan penari sintren maupun pendukungnya. Lagu-lagu yang dimainkan biasanya lagu jawa. Alat music yang digunakan, awalnya merupakan alat yang sederhana. Busana yang digunakan penari sintren dulunya berupa pakaian kebaya (untuk atasan) . Busana kebaya ini lebih banyak dipakai oleh wanita yang hidup di desa-desa sebagai busana keseharian.
Sekarang ini penari sintren umunya menggunakan busana golek yang lebih nyentrik.

Nilai-nilai yang terkandaung dalam seni sintren adalah sebagai berikut nilai religuis, pertunjukan sintren merupakan budaya pra-islam yang masih menggunakan mantra dan mengundang roh halus tersebut dilakukan oleh masyarakat Pekalongan untuk bersih desa atau memohon hujan. Nilai sosial, Dengan mengadakan latihan maka akan tumbuh rasa kekeluargaan dan gotong royong yang kuat.

Nilai keamanan dalam kesenian ini dengan banyak warga yang ikut melihat sehigga hal ini dapat membuat mereka pergi tidur agak malam dan keamanan menjadi lebih meningkat. Nilai seni memiliki beberapa macam, seperti: seni sastra, seni tari, tata rias, seni busana, dan seni dekorasi.

Nilai Hiburan, kehadiran kesenian sintren pekalongan ini kembali di tengahtengah masyarakat di pedesaan tersebut akan mempunyai nilai hiburan tersendiri yang cukup tinggi di tengah-tengah banyak hiburan yang lain yang lebih modern. Nilai ekonomi, pada jaman dulu memperoleh uang dari hasil tanggapan serta temongan dari penonton, namun sekarang dengan sepinya tanggapan maka uang sering diperoleh hanya dari tanggapan saja.

Anton Bakker lahir di Kota Amsterdam, Negeri Belanda pada tanggal 20 Desember 1931. Bakker merupakan putra dari pasangan Henricus Jacobus dan Catharina Bakker. Anton Bakker dalam menjawab persoalan metafisika. Metafisika sebagai sautu disiplin ilmu filsafat memiliki objek material yang-ada, atau dalam bahasa sederhananya adalah hakikat realitas. Membahas tentang hakikat realitas, tidaklah dapat dipisahkan dengan pembahasan tentang hakikat pengada, 
Jurnal Penelitian Humaniora, Vol. 21, No. 1, April 2016: 57-72

baik pengada Yang Hakiki (Tuhan) maupun pengada nonhakiki (ciptaan-Nya).

\section{DAFTAR PUSTAKA}

Ardiyansah, M. 2012. Telaah Metafisika Umum Anton Bakker Terhadap Konsep Ketuhanan Syeh Siti Jenar. Skripsi
(Tidak diterbitkan). Jurusan Filsafat UGM. Yogyakarta.

Bakker, A. 1992. Ontologi Metafisika Umum. Yogyakarta: Kanisius.

Koentjoroningrat. 1985. Pengantar Ilmu Antropologi (Edisi ke-5). Jakarta: Aksara Baru. Ke-5, 1985 